$\mathrm{Z}$ kolei Margarethe Stenzel $\mathrm{w}$ swoim artykule dokonuje porównania kognitywnych map studentów czterech krajów europejskich: Polski, Niemiec, Anglii i Hiszpanii. Raport $\mathrm{z}$ badań nie napawa nas optymizmem i schładza nasze oczekiwania na szybką kulturową integrację z Zachodem.

Artykul Lothara Böttchera i Januscha Dauma jest raportem $\mathrm{z}$ badań nad problemami integracji rodzinnej, szkolnej i zawodowej wysiedleńców przybywających do Republiki Federalnej z terenów bylego Związku Radzieckiego. Celem projektu badawczego, jak podkreślają Autorzy, jest prezentowanie rozwoju tolerancji w obcowaniu z wysiedleńcami, azylantami i cudzoziemcami w kraju zwiazkowym Republiki Federalnej Niemiec.

Z kolei Kazimierz Kossak-Główczewski podejmuje w swoim artykule problem edukacji wielo- i międzykulturowej oraz regionalnej mniejszości kaszubskiej. Autor prowadzi rozważania dotyczace sensu istnienia małych grup etnicznych (narodowych) w obliczu kolonizujących wpływów grupy narodowej (państwowej), która często realizuje projekt grupy dominującej. Odkrywając źródła ideologii dominacji próbuje uzasadnić między- i wielokulturowość jako wyraz pozornej wolności etniczno-kulturowej.

Artykuł Iwony Sagan omawia kwestię przenikania koncepcji miejsca i regionu do programów nauczania geografii. Mimo iż obecne programy nauczania geografii nie wykazują tendencji ku zmianom, to mam nadzieję tak jak i Autorka referatu, że wkrótce geografia sprosta wyzwaniom czasu i będzie kształcić mlodzież świadomą swego zakorzenienia, które jest pożądane z przyczyn społecznych, politycznych i ekonomicznych.

Niniejszy tom zawiera także sprawozdania Alicji Jurgiel pt. Fenomenografia $w$ badaniach nad percepcja wiedzy $w$ dydaktyce akademickiej oraz Marka Ejsmonta pt. Cykliczne konferencje naukowe Zakladu Teorii Wychowania Instytutu Pedagogiki Uniwersytetu Gdańskiego nt. „Edukacja w spoteczeństwie obywatelskim".

Tom kończa recenzje Lecha Mokrzeckiego, Ewy Radziewicz i Jana Żebrowskiego.

$\mathrm{Na}$ zakończenie należy zaakcentować, że omawiane rozprawy będace poklosiem konferencji dostarczyły wiele cennych uwag i spostrzeżeń na temat współczesnej edukacji i kultury. Zawarte w tomie II Ars Educandi teksty inspirowały nas do dysput i polemik na temat konieczności mierzenia się z sensem czasu. Towarzyszyła temu refleksja nad sytuacja kultury, nad jej zagrożeniami, nad rolą w kształtowaniu stosunków między ludźmi, a także w formowaniu postawy wobec życia.

Staranne opracowanie redakcyjne recenzowanego tomu i trafny dobór tematyki czynia z niego bardzo wartościowe wydawnictwo. Najserdeczniej zachęcam do lektury tego niezwykle interesujacego wydawnictwa.

Matgorzata Postuszna

\title{
Zdzisław Dąbrowski, Franciszek Kulpiński, Pedagogika opiekuń- cza - historia, teoria, terminologia, Olsztyn 2000, Wydawnictwo Uniwersytetu Warmińsko-Mazurskiego, ss. 118
}

Pedagogika opiekuńcza jest bardzo młoda dyscyplina pedagogiczną. Jej metodologiczny kształt i główne składniki treściowe są wciąż w stanie tworzenia. Niektórzy teoretycy poddaja nawet w watpliwość odrębne jej traktowanie, np. Irena Jundzilł w swoim Zarysie pedagogiki opiekuńczej traktuje ja jako jeden z kierunków pedagogiki społecznej.

$\mathrm{Z}$ takim podejściem nie zgadzaja się Zdzislaw Dabrowski i Franciszek Kulpiński, autorzy książki Pedagogika opiekuńcza - historia, teoria, terminologia, której recenzję pragnę zaprezentować.

Tytuł wskazuje już na trójdzielny charakter pracy oraz informuje o zagadnieniach, które autorzy pragna przedstawić.

Część pierwsza autorstwa F. Kulpińskiego omawia historyczne podłoże myśli i praktyki opieki nad dzieckiem. Poczynając od średniowiecza a kończąc na czasach wspólczesnych. 
Prezentacje rozpoczyna przedstawienie średniowiecznych instytucji kołowrotka i wuja oraz późniejszą już znacznie działalność ks. Grzegorza Piramowicza.

Osobny rozdział został poświęcony wkładowi królowej Marii Ludwiki Gonzaga, która w XVII wieku sprowadziła do Polski Siostry Miłosierdzia - Szarytki. Zdaniem autora stanowiło to początki rozwoju opieki w naszym kraju i coraz wyraźniejsze jej umacnianie się.

W następnym rozdziale F. Kulpiński analizuje historie rodzinopodobnych zakładów opieki nad sierotami. Przedstawia tu działalność J.H. Pestalozziego oraz formy opieki w Anglii, Belgii, Niemczech i Austrii w XIX i poczatku XX w.

Dla porównania $w$ dalszym rozdziale prezentuje sylwetki prekursorów i reprezentantów pedagogiki opiekuńczej w Polsce: S. Markiewicza, H. Jordana, W. Szejnacha, ks. W. Blizińskiego, K.A. Jeżewskiego, J.C. Babickiego, W. Szumana. H. Radlińskiej, M. Grzegorzewskiej, A. Kamińskiego oraz R. Wroczyńskiego. Zwraca uwagę na charakter pracy i wklad każdej z tych postaci - jednych jako organizatorów i czynnych realizatorów swoich zamierzeń, innych jako twórców teorii pedagogiki opiekuńczej - dyscypliny naukowej.

W kolejnym rozdziale autor jeszcze raz powraca do myśli i działalności pedagogicznej za granica, tym razem prezentujac sylwetki J.H. Pestalozziego, H.Ch. Kofoeda, C. Freineta, A.S. Neilla, S. Szackiego, A.S. Makarenki, W. Suchomlińskiego, J. Addamsa, M. Richmond. Wszystkich ich, choć pochodzili czasem z odmiennych kultur i systemów politycznych, łączył wspólny cel - potrzeba pomocy dziecku, któremu los nie pozwolił wychowywać się w kochającej rodzinie i bezpiecznych warunkach.

Powracając do rzeczywistości Polski przedwojennej prezentuje rodzinne placówki opieki i ich organizatorów, wśród których wymienia ks. B. Markiewicza, K. Lisieckiego, twórce „Ogniska Dziadka”, oraz „Dom Sierot” J. Korczaka, jedynej chyba $z$ najbardziej znanych postaci w omawianej dziedzinie.

W ostatnim rozdziale omówiona zostaje opieka nad dzieckiem w Polsce po II wojnie światowej. Omawia tu autor Gdańską Akcję Letnią Państwowych Domów Dziecka (Galped) oraz ośrodki metodyczne pod kierunkiem W. Dewitz.
Podsumowując prezentację osób i instytucji, których wkład zaważył na historii opieki F. Kulpiński zwraca uwage na sam temat organizacji opieki nad dziećmi w Polsce. Zdania sa tu bowiem podzielone. Czy omawiana dziedzina jest systemem, czy nie? Odpowiedź pada twierdząca.

Dla poparcia swoich poglądów przedstawia elementy budujace ów system. Pierwszym sa tradycje historyczne, bez których wg autora budowanie systemu nie byloby możliwe. Do dalszych elementów zalicza: różnorodne formy opieki całkowitej i częściowej, wychowanków podlegajacych opiece, kadrę realizująca aktualne zadania, warunki materialno-bazowe, organizację pracy w placówkach, metodykę pracy, podporządkowanie administracyjne i nadzór pedagogiczny, publikacje oraz przepisy krajowe i międzynarodowe. Zaprezentowaną przez siebie listę nie uważa za zamknięta, ale traktuje jako propozycję do dyskusji.

Omawiając historię opieki nad dzieckiem, autor doszedı do problemu opieki dzisiaj. Nie potraktował więc historii jedynie jako etapu zamkniętego, wspominanego dla poszerzenia wiedzy czy zaspokojenia ciekawości. Uznał historię za punkt wyjścia. Bez niej nie byłoby możliwe zrozumienie i rozwiazywanie problemów dzisiejszych. W ten sposób widziana historia jest prawdziwą nauczycielka życia.

W części drugiej, autorstwa Zdzisława Dąbrowskiego, przedstawione sa wybrane elementy pedagogiki opiekuńczej. Część ta, jak twierdzi autor, jest skrócona, poprawiona, uzupełniona i uściśloną wersja jego propozycji dwutomowej Pedagogika Opiekuńcza $w$ zarysie (Olsztyn 1995-97). Zawarte tu zostało meritum określające przedmiot pedagogiki opiekuńczej i jej miejsce wśród innych nauk pedagogicznych.

Pracę rozpoczyna przedstawienie pojęciowego modelu pedagogiki opiekuńczej oraz jej charakterystyki jako „nauki o opiece miedzyludzkiej, jej wielorakich aspektach wychowawczych i opiekuńczej waloryzacji wychowania" (s. 101).

Dalej charakteryzuje autor podstawowe funkcje pedagogiczne opieki, oraz jej powiazania z pedagogika ogólna, społeczna, specjalna.

Przedstawia także ogólne pojęcie opieki międzyludzkiej oraz zakres tak rozumianej opieki. Do struktury funkcjonalnej zalicza potrzeby opiekuń- 
cze, funkcje opiekuńcze, postawy opiekuńcze, sytuacje opiekuńcze, czynności opiekuńcze i atmosferę opiekuńczą. Liczba składników strukturalnych sprowadza się tu do syntetycznego wystarczającego minimum, koniecznego warunku aktualizacji właściwego przebiegu opieki. Jest to model rzeczywistej opieki.

Różnorodność przejawów ludzkiej aktywności w dziedzinie opieki, ujawnia potrzebę wyodrębnienia jej różnych wcieleń, czyli kategorii. W tym punkcie swoich rozważań Zdzislaw Dąbrowski wskazując na powiązania pedagogiki opiekuńczej z innymi dziedzinami życia i działalności wyodrębnia jej różne kategorie - kategorię opieki, rodzinna, społeczną, lecznicza, religijna, moralną, prawną, wychowawczą i ekonomiczna. Najwięcej problemów sprawia zdaniem autora wyodrębnienie opieki jako kategorii wychowawczej. Proces opiekuńczo-wychowawczy jest bowiem często widziany jako nierozdzielny. Należy jednak dokonać rozdziału, aby uniknać pomieszania czy nakładania się pojęć. Kolejny rozdział został więc poświęcony ustaleniu relacji między opieką a wychowaniem.

$\mathrm{Z}$ przeprowadzonej analizy wynika, że relacje maja w większości charakter obiektywnych zależności. Pojęcie „opieka” i „wychowanie” najczęściej krzyżuja się choć czasem są sprzeczne, przeciwne, tożsame lub niezależne.

Ostatni rozdział omawia podstawowe swoistości aksjologii opieki. Autor stwierdza, że opieka opiera się przede wszystkim na wartościach allocentrycznych, wyprowadzonych bezpośrednio z wartości najwyższej - człowieka-podopieczne- go. Wartości te sa kategoriami realnymi zawierającymi się w osobie i egzystencji podopiecznego.

Porównując obydwie części książki wyraźnie widać jak rozwinęła się pedagogika opieki. Z dzialalności spolecznej, „odruchu ludzkiego serca" stała się samodzielną dyscypliną naukową z zapleczem metodologicznym i teoretycznym.

Zdzisław Dabrowski w bardzo przejrzysty sposób przedstawił dyscyplinę naukową, którą się zajmuje. Bardzo pomocne sa liczne wykresy i tabele szeregujące zwięźle i obrazowo omawiane tematy.

Trzecia część prezentowanej książki, również autorstwa Zdzisława Dąbrowskiego, jest zebrana terminologia pedagogiki opiekuńczej. Autor nazywa ja ,przysłowiowym gwoździem programu" ze względu na nowatorstwo i innowacyjność ujęcia. W porządku alfabetycznym zostały przedstawione podstawowe pojęcia, którymi posilkuje się pedagogika opiekuńcza. Jednocześnie część ta jest jakby syntetycznie zebraną interpretacja części drugiej i umożliwia szybkie znalezienie potrzebnego terminu. Uszeregowanie haslami w formie słownika jest bardzo przydatne dla studentów a także dla osób zajmujących się zawodowo opieka nad dzieckiem.

Choć autor głównie trzecia część nazywa nowatorska, wydaje się, że cała praca zasługuje na takie miano. Nie tylko ułatwia studiowanie, ale także przedstawia w sposób skondensowany duży zasób informacji o tej młodej, ale wciąż dynamicznie rozwijającej się dyscyplinie naukowej.

Anna Sobków

\section{Domus et Familia - ideały życia rodzinnego, red. Ilona Błaszczyk i Juliusz Jundziłł, Bydgoszcz 2000, ss. 107}

Tematyka prezentowanej książi obraca się wokół zagadnień wychowania w rodzinie, przedstawionego $w$ aspekcie historycznym. Na uwage zasluguje również chęć ujęcia tego zagadnienia tak, aby zaznaczyć aspekty jak najbliższe współczesności.

W literaturze historyczno-pedagogicznej niewiele miejsca poświęca się badaniom historii rodziny, zwłaszcza w bardziej odleglej przeszło- ści, starożytności czy średniowieczu. Tak więc celem niniejszego tomu rozpraw jest ukazanie analizowanych zagadnień tak, aby można je było odbierać w kategoriach zastosowań we współczesnych badaniach funkcjonowania rodziny, a zwłaszcza dydaktyce na kierunkach historii i pedagogiki.

Recenzowana praca składa się z krótkiego Wstępu i artykułów dziesięciu autorów. Wśród 